This is the Author's Accepted Manuscript version, uploaded in accordance with the publisher's self-archiving policy. Please note: this is the author's version of a work that was accepted for publication in Social Science \& Medicine. Changes resulting from the publishing process, such as editing, structural formatting, and other quality control mechanisms may not be reflected in this document. A definitive version was subsequently published in Social Science \& Medicine, Volume 124, (January 2015), DOI 10.1016/j.socscimed.2014.11.045.

The definitive version is available at: $\underline{\text { http://dx.doi.org/10.1016/j.socscimed.2014.11.045 }}$ 


\title{
When does marketisation lead to privatisation? Profit-making in English health services after the 2012 Health and Social Care Act.
}

\author{
Nick Krachler (Cornell University) and Ian Greer (University of Greenwich) \\ njk77@cornell.edu, $\underline{\text { i.greer@greenwich.ac.uk }}$
}

Draft September 2014, forthcoming in Social Science and Medicine.

\begin{abstract}
Governments world-wide have attempted to use market mechanisms and privatisation to increase the quality and/or reduce the cost of healthcare. ${ }^{1}$ England's Health and Social Care Act 2012 is an attempt to promote privatisation through marketisation in the National Health Service (NHS). While the health policy literature tends to assume that privatisation follows from private-sector entry points, we argue that this is more likely if firms expect to make a profit. This paper examines the link between privatisation and marketisation in England drawing on 32 semi-structured interviews with private-sector and public-sector respondents, campaigners, and other experts conducted 6-10 months after the implementation of the 2012 Act.

By generating a theoretical framework on the conditions of profitability we seek a better understanding of the conditions under which marketisation leads to privatisation. We find that significant barriers to profit-making remain after the reforms, including a top-down squeeze on prices, uncertainty in market rules, state dominance of funding and provision, and failures to depoliticise the market. These factors restrict private-sector involvement by frustrating profit-making. Where profits are made they are through reduced unit costs and high volumes by a longstanding incumbent in a particular market segment. This, however, restricts marketisation by reinforcing entry barriers.
\end{abstract}

Keywords England; Marketisation and Privatisation of Healthcare; For-profit Healthcare; National Health Service; Health and Social Care Act 2012

\footnotetext{
${ }^{1}$ We are grateful to Liz West and Stephen Bach, as well as SSH editor Stefan Timmermans and two anonymous reviewers, for very helpful comments. We also gratefully acknowledge financial support from the University of Greenwich and the European Research Council grant 313613, the Effects of Marketization on Societies (TEMS).
} 
Market mechanisms have become general-purpose tools for public policy, and health services are no exception. With the Health and Social Care Act 2012 (referred to here as 'the Act') the UK Government sought both to marketise (i.e. increase price-based competition between providers) and privatise (i.e. increase provision carried out by non-government providers). While the Act's supporters argue that competition will provide innovation, better management, and improved quality (Le Grand, 2013), its critics argue that it will exacerbate health inequalities (Hunter, 2013) and service rationing (Lister, 2012), end comprehensive public-sector health service provision (Pollock and Price, 2011), and worsen democratic accountability (Davies, 2013). Peedell (2011) shows that the Act's objectives fit most commonly accepted definitions of privatisation, and Moody goes as far as to say that, in the future, "there will be no fully state-owned providers" (2011: 428-429).

It is unclear, however, whether the Act will deliver on these hopes and fears. Despite a decades-long marketisation process, the state remains dominant, both as funder and as provider, with private-sector involvement in the NHS estimated at around 19\% for provision including general practitioners (GPs) (Klein, 2005) or 12.3\% of government secondary care expenditure (Arora et al., 2013). While Germany has privatised by selling entire hospitals to profit-making firms (Anonymous, 2013a), the UK has contracted out particular services to private providers. Limits to privatisation include state dominance in funding (Moody, 2011), economies of scale in public-sector provision (Davies, 2013), the conservatism of public management (Radnor, Holweg and Waring, 2012), and centralisation in contracting (Petsoulas et al., 2011). The private sector shares this scepticism: in a 2012 survey of private healthcare professionals, only 20\% expected increased competition (Nabarro and HealthInvestor, 2013). This uncertainty about the NHS reflects broader uncertainty concerning the conditions under which marketisation translates into privatisation. 
This paper explores the relationship between marketisation and privatisation drawing on 32 qualitative interviews with private-sector consultants and business-development professionals, commissioners of services, trade unionists, and other experts and campaigners. The private sector, we argue, is more likely to invest and expand in a market structure where it expects profits. We focus on six conditions of profitability hardly affected by the Act. Four barriers include (1) the top-down squeeze on prices associated with austerity and limited budgets, (2) the uncertainty associated with ever-changing rules and administrative practices, (3) state dominance in financing and provision, and (4) the failure by pro-market policymakers to depoliticise the market. Where profits are realised, it is due to (5) reduced costs and (6) increased volumes. These latter two conditions reinforce the status of incumbents, which counters marketisation by reinforcing barriers to entry.

\section{Marketisation and privatisation in English healthcare}

Marketisation is, as we define it, a change in transactions, through the introduction or intensification of price-based competition. This can take place through an increase in the standardisation of the good or service being exchanged, the frequency of exchange, the openness of the market to new providers, and/or the transparency and importance of the price mechanism (Anonymous, 2013b). Privatisation, by contrast, is a change in ownership in which non-state actors become increasingly involved in provision, usually through a transfer of assets (e.g. the sale of a hospital) or an increase in work contracted out (Peedell, 2011). We exclude from our definition 'hybrid' organisations like Foundation Trusts because they remain part of the state (Davies, 2013), and refer mainly to for-profit providers, because the market share of non-profits is low in English healthcare (CMA, 2014). While the opening of the market to private-sector providers is an important aspect of healthcare marketisation, intense price-based competition and an expanding non-state sector do not always go together. 
The NHS has used market logic, including price mechanisms and competition, since purchasing was separated from provision under the 'internal market' of the early 1990s (Light, 2001). The internal market, however, was accompanied by directives limiting purchasing and borrowing by Trusts (Propper and Bartlett, 1997), and it was plagued by geographic monopolies, healthcare workers' persistent professional ethos, public pressure against destabilising traditional providers, and tensions between managers and politicians (West, 1997).

Governments have also attempted to stimulate competition by creating private-sector entry points: the 1983 mandate of competitive tendering for ancillary services (Klein, 2006), the 2002 introduction of Independent Sector Treatment Centres (ISTCs) in secondary care (Bishop and Waring, 2011), and the 2003 abolition of GPs' monopoly for out-of-hours service in primary care (Pollock et al., 2007). Despite these opportunities, however, private providers still account for a small share of NHS commissioning: in 2011/2012, PCTs spent $£ 5.22$ bn on for-profit providers, $12.3 \%$ of their total secondary care budget (Arora et al., 2013). Why is this? In the ISTC programme, negative media reports, pressure from campaigners, hostility from NHS staff, and the unwillingness of some Trusts and Primary Care Trusts (PCTs) to send patients to ISTCs led to a reduction in contracts in the second wave from 24 to 10 (Gabbay et al., 2011). Despite their high visibility, ISTCs were limited to $1.8 \%$ of elective care in 2007/2008 (Bishop and Waring, 2011).

Private-sector providers depend heavily on NHS commissioning, because it is by far their largest potential source of income (Figure 1). In 2011 the government accounted for $82.7 \%$ of health spending (WHO, 2014), and of the overall £108bn NHS budget (HM Treasury, 2013), £64.7bn are allocated to CCGs, £30bn comprise the budget of NHS England, and $£ 0.9$ bn are distributed to local authorities for the provision of selected public health services (NHS England, 2014). The private medical insurance market, by contrast, 
covered $10.9 \%$ of households in 2012 , a decline of $1.6 \%$ since 2006 ; corporate schemes comprise $80 \%$ of this market (Arora et al., 2013). In one large survey only $6.9 \%$ of respondents reported intending to exit the NHS for private healthcare (Dowding and John, 2011) and in another only $3 \%$ of British respondents reported spending above 1000 US\$ in 2013 (Schoen et al., 2013).

\section{Figure 1. Healthcare spending in the UK}

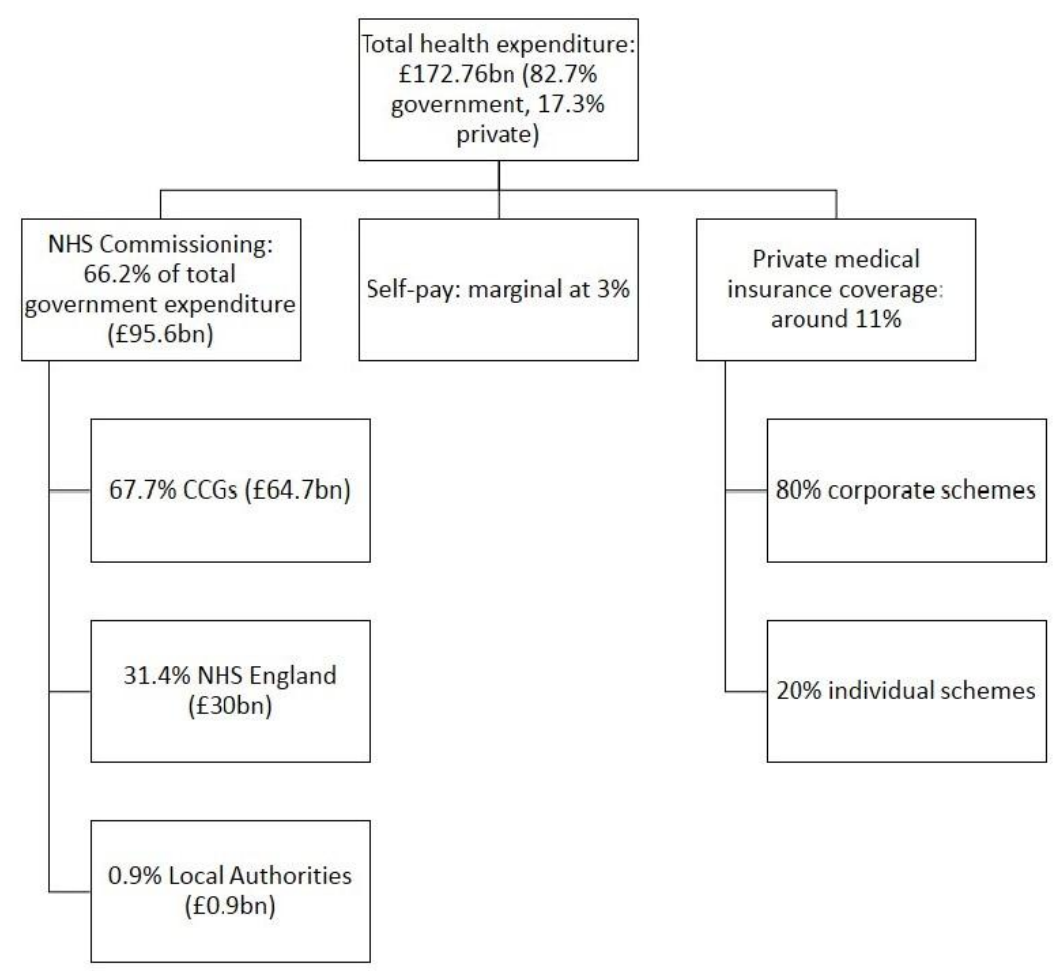

With $9.3 \%$ of GDP spent on health (compared to the USA's 17.9\% [WHO, 2014]), the NHS is adept at containing costs; this is visible in commissioning practices and in-house management. Around £29bn of services are commissioned using 'Payment by Results', a pricing system for particular diagnoses also known as 'the tariff', introduced in 2003/2004 (Department of Health, 2012). Since 2006 these reimbursement rates have incorporated annual efficiencies of 3\%. Furthermore, for nonmedical NHS staff, the Coalition Government has restricted pay increases to 1\% (Office of Manpower Economics, 2013) and reduced capacity. Examples of the latter include the restructuring of four Accident \& Emergency Departments into Urgent Care Centres (NHS North West London, 2013) and the closure of 
53 Walk-In Centres between 2010 and 2013 (Butler, 2013). The aim is to achieve $£ 20 \mathrm{bn}$ of savings by 2015 (HM Treasury, 2013), 18.5\% of the NHS’s $£ 108 \mathrm{bn}$ budget. This squeeze is intensified by even deeper cuts to local authority budgets - 30\% from 2010 to 2014 - which could undermine the social determinants of health, thereby increasing demand for services.

The government's main lever for opening the market to the private sector has been commissioning. While commissioning had previously been carried out by 151 Primary Care Trusts (PCTs) and 10 Strategic Health Authorities, the Act changed it to 212 Clinical Commissioning Groups (CCGs) and NHS England. CCGs are dominated by GPs, but also include lay members, hospital doctors, and nurses; they purchase clinical services for a geographically defined population of patients. NHS England commissions primary care services and specialist services such as screening. The regulatory infrastructure includes (in addition to the Department of Health) the 'Health and Wellbeing Boards' advising CCGs; 'Monitor' regulating Trusts, enforcing competition, and setting the tariff; the 'Care Quality Commission' regulating quality; and 'Public Health England', which shares the public health function with local authorities. Marketisation is thus underpinned by complex and fragmented administration and regulation.

The Act has other important marketising elements. One is Section 75 , which mandates open and competitive tendering for services commissioned by CCGs. However, it also allows contract renewals with existing providers after competitive tendering if patient benefits and the transparency of the process can be demonstrated, and allows the NHS to litigate against uncompetitive contract awards to private providers (Davies, 2013). Other provisions pertain to the internal management of Trusts. The Act establishes a 'failure regime', under which hospitals with financial troubles can be put under special administration and plans to reconfigure the local health economy drawn up and implemented. The Act also universalises Foundation Trust status, which increases management autonomy by, among other things, 
allowing private patient income to increase to $49 \%$ and allowing the retention and reinvestment of surpluses.

While marketisation and privatisation form the core of the Act's logic, the practical consequences are uncertain. While one report showed around $70 \%$ of contract awards from April to December 2013 awarded to non-NHS providers (NHS Support Federation, 2013), the volume of the work represented and the degree of change this represents is unclear. While policymakers have identified the contracting out of certain activities, such as pathology, as a major cost-saving opportunity for the NHS (Coles, 2008), it is unclear how widespread such exit options are. The Act increases management autonomy within Trusts, which could make public-sector market incumbents more competitive, reinforcing barriers to entry. Finally, the commissioning and regulatory infrastructure created by the act is fragmented, and CCG members may see themselves as more accountable to the public than to market-making regulators (Checkland et al., 2013). The Act's effect on the behaviour and perceptions of commissioners and providers is thus unclear.

Absent from the empirical NHS literature is the issue of profit-making, i.e. the realisation of surpluses that can be reinvested or distributed to owners. This latter gap is surprising, not only because most large contractors are for-profit and therefore need profits to justify investments, but also because profit-making may exacerbate health inequalities (Scambler, 2009), drive up costs (Hellander et al 2013), and lead hospitals to specialise in lucrative treatments (Horwitz, 2005).

\section{The conditions of profitability}

To generate our framework we draw on institutional political economy, economic sociology, and the international health policy literature. These literatures suggest several reasons why privatisation presupposes profit-making, but why not all forms marketisation lead to 
profitability. Profit-making may increase incrementally through the prospect of appropriating small proportions of resources in a given health system (Jensen, 2011), but not necessarily take the form of a large-scale long-term appropriation of resources by the private sector. Since total expenditure equals total provider incomes, "more expenditure always yields an increase in income" (Evans, 1997, 443); less expenditure leads to intensified competition over available resources and, hence, reduced likelihood of profit-making (Keegan et al., 2013). Entry points for private providers do not automatically produce an increase in profitmaking, since profitability depends on specific conditions. What are they?

First, the availability of resources to private providers is important and may be constrained by the politics of austerity. Arguably austerity is conducive to privatisation, since it creates gaps in provision or investment backlogs that are then compensated through private means. In the Norwegian NHS in the 1990s, for example, high county revenues were associated with higher demand for public provision whereas low county revenues increased privatisation (Midttun and Hagen, 2006); and in Germany a squeeze on investment created the preconditions for rapid privatisation of hospitals (Anonymous, 2013b). On the other hand, austerity may not necessarily be conducive to privatisation, since it reduces the overall amount of money available to contractors. Jane Gingrich's (2011) concept of 'austerity markets', employed to analyse the Conservative Government's health policies in the 1980s, captures this ambivalence.

Associated with austerity is the drive by politicians and commissioners to maximise value for money which can reduce profit margins. This squeeze of prices for contracted work is facilitated by activity-based funding in which prices are fixed in a top-down manner in England using data from NHS providers (and not from private providers [O'Reilly et al., 2012]). There is evidence that the privatisation of GP services by New Labour was limited 
due to such a top-down price squeeze by commissioners which resulted in firms "finding it difficult to make a profit" (Allen and Jones, 2011, 23).

A second condition is the degree of uncertainty built into the market structure, which shapes the calculation of risks and potential returns. Without stability or predictability in the parameters of a market, private providers are less likely to enter the market (Carruthers and Ariovich, 2004). Stability is often ensured by regulatory and state institutions enabling reliable calculation (Callon and Muniesa, 2005) which permits predicting returns on investments regarding market entry and innovations. Conversely, a lack of calculability reduces incentives to invest (Fligstein, 1996) and hence, profitability. For non-profit organisations working in English healthcare, uncertainty in the commissioning process is a well-documented problem (Rees, Miller and Buckingham, 2014).

Third, the degree of competition from the public sector is important, since for-profits have to match the production costs of NHS providers in order to gain market share. Public provision has in-built advantages in price-based competition: economies of scale and not needing to distribute profits (Gough, 1979). Furthermore, the traditional public-sector ethos in the NHS enables "delivering high quality services at a relatively low cost" (Hebson et al 2003, 492), but which can equally be eroded by performance-related pay when workers transfer into for-profit organisations. Moreover, state dominance in funding means strict limits to for-profit firms increasing their revenue from self-payers or private insurance. Private providers depend on winning government contracts and have difficulty competing with the NHS's extensive service portfolio, instead focussing on the limited supply of private-sector income, predominantly for elective treatments (CMA, 2014).

Fourth, the political process - including the depoliticisation of controversial reforms matters, because it redistributes power. Market reforms tend to undermine the power of public service workers, but have varying effects on public-sector managers, private providers, 
and service users; they may empower one or more of these actors, but not all of them (Gingrich, 2011). For example, supplier opportunism in the context of Private Finance Initiative contracting in the NHS leads public-sector managers to employ detailed planning practices (Lonsdale and Watson, 2007) and hold private-sector managers accountable to contract specifications (Hebson, Grimshaw and Marchington, 2003), potentially leading to a more difficult situation for profit-making. Moreover, commissioning in English healthcare has traditionally limited competition, since patient choice and cash budgets were both strictly limited (Sheaff et al., 2013).

Furthermore, the power of business interests in the political process depends on the importance of the issue at stake to voters and its exposure in the news media. For issues of low 'salience' business almost always gets its way, but otherwise government can have difficulty merely deferring to the expertise of business (Culpepper, 2010). Despite policymakers' attempts to depoliticise reforms by drawing attention away from the core principles of marketisation and privatisation (Leys and Player, 2010), campaigns in England against privatisation are widespread and ongoing (Ruane, 2011).

Finally, certain managerial practices constitute another condition of profitability. These practices can be divided into increasing revenues and reducing costs. Expected cash flows from demand are weighed up against costs stemming from factors like infrastructure investment, a need for economies of scale and retaliation from incumbent providers (Lethbridge, 2011). Demand itself is relative to the size of a market and its accompanying spending power (Dicken, 2011). Furthermore, the quality of labour regarding skills, wages, and unit costs has also been conceptualised as an important investment factor (ibid). The ISTC programme provides some indication of how profits are made in English healthcare, namely by lowering unit costs and driving "the standardisation of work and a performance regime" (Turner et al., 2011, 527). The little evidence that exists indicates non-NHS 
providers are able to match the quality standards of NHS providers, without, however, providing higher quality services (Propper and Dixon, 2011) or medical innovation (Turner et al., 2011, 528). Moreover, Foundation Trusts are also aggressive in expanding market share and can make decisions quicker due to their enhanced autonomy (Allen and Jones, 2011), and may have become more efficient due to increased competition (Propper and Dixon, 2011). These studies indicate that profits are made by lowering unit costs, but that the NHS may be more innovative and increasingly cost-competitive.

Our research questions concern the conditions of profitability in health-care markets. What are the constraints on profit-making under the 2012 Act? What are the effects of austerity, state dominance, uncertainty, and the political process? Where private-sector management does succeed in profit-making, what are its strategies?

\section{Methodology}

While most studies of the 2012 Act are based on policy and legal documents and were written before CCGs took up their statutory duties, ours is based on interviews conducted 6-10 months afterwards. We chose a qualitative approach to explore profit-making and marketisation in health services in order to capture the perceptions and rationales underpinning management decisions. We focus on health services and leave aside other NHS-funded market segments, such as consultancy, infrastructure financing, pharmaceuticals, information technology, and ancillary services, which differ from health services in terms of task, actors, and regulation. We focus on England, leaving aside the UK's three devolved countries, since the 2012 Act does not apply to them, and since marketisation has gone furthest in England (Greer, 2008).

We conducted 32 semi-structured interviews with 34 participants (twice we interviewed two participants together). Our sample includes 15 private-sector representatives, 
of which 10 were senior managers (in radiology, pathology, hospitals, global service provision and home care) and 5 were management consultants (including 4 partners). We also interviewed 6 public-sector representatives (including 2 from regulatory agencies, 1 finance manager of an FT and 1 commissioner) and 5 trade unionists (including senior officials, regional organisers and researchers). Additionally we spoke to 4 clinicians (2 GPs and 2 CCG members), 3 campaigners and 1 healthcare researcher. The private-sector participants all had at least 5 years' experience working in senior management positions in profit-making enterprises and 10 years of experience in the private healthcare market. Additionally, several had extensive clinical experience, and/or experience working in the public sector, and/or experience abroad, in Australia or the USA.

We chose our sample purposefully for "theory triangulation" (Patton, 1999, 1196) using the differing perspectives of stakeholders (private-sector managers, public-sector representatives, unionists and campaigners) to cross-check their various interests. Most of our sample comprises private-sector business development managers and managing directors. While this seems to give us low generalisability, the strategic decisions in this sector are made by a few people, mostly in senior management. By interviewing other stakeholders we were able to probe the same set of issues with different individuals with varying interests (e.g. pro-market versus anti-market and purchaser versus provider) and knowledge. The case study is triangulated further by the use of publicly available statistics and research reports, which we cite below.

All interviewees were asked about the impact of the Act and austerity measures, the relevance of campaigning and unionisation for their work and their organisations. Privatesector participants were additionally asked about their competitive advantages compared to the NHS and whether the Coalition Government's health policies had created better conditions for developing business and winning contracts. Interviews with unionists and 
campaigners focused additionally on labour issues and the efficacy of campaigning, while interviews with civil servants scrutinised policy intentions and the new regulatory framework.

The interviews lasted approximately 60 minutes on average. They were recorded, part-transcribed and coded line-by-line and thematically with MAXQDA. The focus was on key segments, selected by the researchers as relevant to the main research questions. Then the interviews were coded by both researchers along the emergent themes of austerity policies, commissioning reform, profitability barriers and profit-making avenues; these themes were identified through memos, email exchanges, and in-person discussions. The data were analysed 3 times, starting with an inductive approach (both researchers exploring the transcripts and attaching codes in a relatively ad-hoc fashion) and ending with a top-down approach (one researcher more systematically coding using an agreed-upon coding scheme). Between iterations, the co-authors discussed differences in interpretation until they reached agreement and then revised the coding scheme (Campbell et al., 2013).

Written consent was received from each participant via a consent form sent at least two days prior to interviewing, and University ethics approval was obtained.

\section{Findings 1: Perceived profitability barriers}

Above we introduced barriers to profitability by discussing the macro-structure of the English healthcare market. In the following sections we discuss four areas in which our interviewees found market dynamics frustrating to profit-making.

Uncertainty in rules. Our interviewees were disappointed by a lack of clarity surrounding competitive tendering requirements. While CCGs are bound by competition law and EU regulations, a lack of bids does not require re-tendering if the process is transparent, "the providers were able equally to bid for it" (CCG GP Member), and the value of remaining 
with incumbent providers is demonstrable. Moreover, attempts to reduce external tendering were reported and the ability to challenge tendering outcomes was described as limited by some private-sector managers, since litigation can strain the relationship with the funder.

Our interviewees reported uncertainty in the rules of competition built into Section 75, other issues like when VAT can be claimed back by the private sector, and the reality of periodic top-down NHS reorganisations. This turmoil can cause periods of revenue-losing inactivity: "it's almost like the system takes a breath and stands still for a year [...] everyone needs to find their feet, find out how the new system works" (Development Director Radiology 1).

The decision-making process within the NHS was described as slow and uncertain: "policies change by the time somebody's made a decision, it's quite frustrating" (Director Home Care). When reorganisations incorporate personnel changes, they disrupt the flow of data and relationships between provider and funder: "It's almost as if we have no track record as a provider, which has been really, really frustrating” (Development Director Radiology 2). Frequent policy changes lead to uncertainty, since services may become redundant: "there have been some well-documented organisations who spent a lot of money and have withdrawn because they've not seen their return on investment [due to policy changes]" (Director Global Service Provider 1). One service provider reported demanding a contract length of five years rather than the standard one year due to upfront investments.

The lengthy and costly procurement process also contributes to uncertainty. Advertisement to contract award in the NHS generally takes 18-24 months, and interviewees report that the investment needed for participating in tenders can exceed the likely returns of the contract. In addition, four private-sector managers complained of losing upfront investment due to the NHS cancelling tenders: “it's like playing roulette with quite big stakes" (Managing Director Pathology). 
The complexity and fragmentation of regulation also contributes to uncertainty. The number of regulatory bodies increased from 175 to 300 (not including commissioning), and the Department of Health's role in implementation was reduced by a cut in its management consultancy budget, which led to a multiplication of approval stages for system changes. This fragmentation frustrated, for example, the creation of large regional contracts with multiple CCGs: "The whole East of England did a big procurement around GP pathology, it took two years and [NHS organisations] were going to lose 10 million pounds of revenue [...] though results were announced and [private providers] spent 10, 15 million pounds doing it, it didn't go ahead" (Managing Director Pathology).

The top-down price squeeze. Interviewees also often reported a top-down squeeze on prices resulting from austerity, which reduced available resources. Margins on NHS commissioning were described as eroding or low compared to other revenue streams: "there's definitely margin erosion. The margins in the NHS are much lower than they are in our pharma or private business" (Development Director Home Care).

The NHS as funder demands efficiency: "we have to work even harder, because we have to produce a margin and then we have to produce the gain and the efficiencies that the commissioner wants" (Director Global Service Provider 2). Achieving profits through NHS commissioning is further complicated by the importance of quality, which can lead to the inability to deliver services according to contract specification: "[the for-profit provider] could not deliver the quality for the price agreed [...] we re-tendered at the end of the contract. They chose not to bid and in fact stopped offering that service and the contract was then won by a consortium of a non-local NHS provider and a local voluntary provider" (GP).

The steady reductions in the tariff, which is calculated as an average of reported NHS provider costs, also squeezed resources. A recurrent theme in interviews was that poor- 
quality data submitted by NHS providers drove down reported average costs, sometimes below market rates. In one extreme case, Trust delivery costs for PET-CT scans were reported at between $£ 99$ and $£ 1300$, despite necessary isotopes costing $£ 100$.

State dominance of funding and provision. The third profitability barrier reported is the dominance of the state. Participants complained that the market had not really opened, and six interviewees described it as 'immature', despite marketisation and privatisation trends since the 1980s. They pointed to a lack of funding beyond NHS commissioning due to low private medical insurance coverage and the scarcity of patients paying out-of-pocket. Private insurance is only offered as a high-cost, elective product which does not cover a broad range of healthcare services, most notably emergency services. Executives at multinationals pointed to countries with private medical insurance as more lucrative markets.

The nature of CCGs is one source of private-sector disappointment. Decision-making processes were described as more formal and difficult to influence after the Act. Moreover, CCGs tend to structure provision in detail rather than letting providers decide how to comply with contract specifications. Contracts were also often small due to the decentralised nature of CCGs, and providers reported frustration in their attempts to create larger contracts with longer running times. Interviewees reported contracts as often too small-scale to attain returns on investments.

Our private-sector interviewees characterised CCGs as uninterested in stimulating privatisation. CCGs have "gone straight back to how it used to be" (Director Hospitals 1) with strong links to incumbent NHS providers. Equally, they were deterred by the possibility that, by switching to private providers, "you could destabilise a whole organisation" (CCG Lay Member). A further limitation was that commissioning expertise was lost in the transition to CCGs and that the remaining members were "much more about keeping the system going" (GP). Moreover, GP interviewees were not interested in stimulating 
privatisation, and one private-sector interviewee argued that many CCG members "didn't become GPs to manage a budget" (Consultancy Partner 2).

In addition, because of the range of high-quality services provided by the NHS and its ability to cross-subsidise, private sector interviewees reported difficulty competing with the NHS for certain treatments: "I think there are services that have to be provided by the NHS [...] There's specialist things that a private company will never do, it would be too expensive or too specialist" (Pathology Management Consultant). Additionally, the NHS was characterised as "best in terms of value for money [...] no other system provides as comprehensive a coverage at such high quality" (Consultancy Partner 1).

Internal public-sector restructuring posed an additional challenge to the private sector, because - together with public-sector management autonomy under Foundation Trust status it intensified the NHS's cost advantages. Due to pressures on terms and conditions, increased workloads, and downbanding, NHS workers felt "the restrain of resources, trying to stretch over those gaps by working an exhaustive number of unpaid overtime [but] there's downgrading, removing their clinical worth" (Senior Union Official). Moreover, Foundation Trusts could establish new businesses to circumvent collectively bargained work hours and pay grades: "we've got through subsidiary companies out of Agenda for Change" (FT Finance Manager). Several had also established gateway clinics in the Middle East to funnel private patients to the UK.

The reliance on NHS commissioning restricted the private sector's viable revenue streams and hence its service portfolio. Our interviewees interpreted this as a lack of muchneeded government support, which, one argued, "does not happen without being forced" (Director Hospitals 2). 
Failed depoliticisation. The last barrier is the inability of for-profit providers and pro-market policymakers to de-politicise the market. Because of the high value placed on the NHS by the British public, privatising healthcare is a risky proposition for politicians: "the NHS is probably the one area of public sector that's absolutely sacrosanct" (Consultancy Partner 2). Consequently, prior to the passage of the Act, the Government denied, disingenuously, that privatisation was intended (Peedell, 2011).

The NHS employment relations system contributes to politicisation, due to high union density, collective bargaining coverage (Brownlie, 2012), and the high degree of professionalisation. Campaigning groups such as Save Our NHS and Keep Our NHS Public draw attention to privatisation and private-sector service failures. As a result several privatesector interviewees bemoaned the orientation of staff towards professional autonomy and the public interest rather than performance as defined by management.

Negative media reports were also named as difficulties in growing business. The media was seen as reporting sensational stories of service failures and negative patient experiences: "They [the media] love it when we get it wrong, they're not remotely interested when we get it right, at least that's not where the national mood is" (Development Director Radiology 2). Negative media reports could damage brand value and a company's reputation: "those levels of scrutiny create newspaper headlines and stories $[\ldots]$ of concern to boards" (Director Global Service Provider 1).

Campaigning was generally seen as anti-privatisation and almost successful in stopping the enactment of the Health and Social Care Bill 2011. A top-down reorganisation by the Coalition Government had not been expected, as party manifestos explicitly rejected this. Enactment was therefore described as "one of the most aggressive, quick policy, rushing through things that have not been scrutinised" (Researcher and Unionist) causing resentment and disappointment. Moreover, campaigning was fuelled by the impact of austerity and 
reconfigurations: "it's very easy for the public to imagine what's going to happen when someone says: 'We're going to close your local hospital', they've got an immediate emotional attachment, often members of their family were born or died within that hospital" (Researcher and Activist 1).

The degree of politicisation varied according to the type of service provided, with highly visible services attracting attention from patients, staff and the public. Clinical services and services directly involving patients are highly visible, triggering demonstrations, with the University Hospital Lewisham - the first time the Act's "failure regime" was triggered, which could have led to privatisation - being an extreme case: "South-East London, they hadn't had a protest like the Lewisham Hospital for years and years and years, 25,000 people to defend one hospital in one borough" (Researcher and Activist 2). Where the private sector was established, services tended to be less visible and more removed from public scrutiny. Community health services, for example, were seen as opaque because they dealt with marginalised social groups, and pathology worked "behind the scenes" (Pathology Management Consultant).

Our interviewees reported attempts to avert attention by employing little public relations activity: "We take a marketing-by-stealth type approach [and] tend to just quietly grow our business" (Director Home Care). In areas of trade-union strength, managers reported in addition consulting with worker representatives to avoid resistance: "One of the key things that has happened in all the projects across the country I've seen is that the unions have always been involved at a very early stage, always been consulted and part of the main decisions" (Pathology Management Consultant).

\section{Findings 2: Profit-making in particular segments}

While the system restricts profit-making, segments do exist where profits are realised. The privatisation of the community health services sector, for example, started in the 1980s, and 
by $2000,69 \%$ of spending was on private services (Player and Pollock, 2001). Radiology, pathology and mental health were also named by interviewees as profitable, and some reported an increase in tendering activity (for one home care provider the number of tenders in play had doubled in 2013) or contract size, as well as attempts in the hospital segment to profit from increased waiting times by serving self-payers seeking to jump the queue. The NHS's reduced investment capacity was also described as a private-sector opportunity in some market segments, since it prompted Trusts to consider outsourcing. The bulk of the work reported, however, was repeat business by incumbents. In these cases there were two main avenues for profit-making: cost reduction through performance management, process optimisation, greater asset utilisation and reduced personnel costs; and achieving high and stable volumes.

Reducing costs. Efficiencies are gained partly through managing staff differently from the NHS. Low pay in the NHS is compensated with a high degree of professional autonomy, which reinforces a public-sector ethos and upholds quality standards (Hyde et al., 2009). Private providers depart from this formula through the avoidance of collective bargaining and tight performance management.

Lower personnel costs result, first, from employing lower-skilled workers. In pathology, "a lot of band 6s and 7s manage the equipment [in the NHS]. You go to Europe or any of the new labs in the UK, you see band 3s and 4s" (Pathology Management Consultant). Deskilling is complemented by increased patient turnover achieved using lean management techniques. Lower levels of unionisation and collective bargaining coverage are crucial, since the Agenda for Change stipulates increased pay during unsocial hours. This advantage is mitigated in cases where contractors employ former NHS staff under transfer of undertakings 
(TUPE) rules that protect their terms and conditions of employment. Contractors facing these requirements face increased production costs, according to one director, of $12 \%$.

At the same time work is tightly managed using IT. This includes monitoring: "we've got complete visibility about what [nurses] do, when they do it, how long it takes" (Director Home Care). Control is facilitated by standardisation. Executives argue that performance management of staff is a central part of strategy: "we can take the established infrastructure and personnel and deliver more quickly best practice [and eliminate] poor performance" (Director Global Service Provider 2).

A final technique for reducing unit costs is intensive asset utilisation. In radiology, for example, private-sector interviewees reported a higher rate of average scans than the NHS, sometimes almost double the amount. Because of working-time rules the NHS cannot continually utilise its assets, instead sometimes using a machine worth $£ 1.5 \mathrm{~m}$ only $4-5$ hours per day (FT Finance Manager).

Increasing volumes. Attaining large volumes in particular segments is the other avenue for profit-making. Before achieving a high volume of business, a private healthcare company is usually loss-making until it attains a high enough market share to generate sufficient returns to be profitable. Obtaining large volumes is also important for gaining access to capital and reducing purchasing costs, especially in technology-driven areas such as hospitals and radiology, where austerity policies limit the NHS' ability to borrow.

Large scale can be achieved in various ways. One is specialisation in one area and provision across a large geography: "So what they've now marketed is 'We can do your specialist tests' [...] so what's actually happening is we're getting an enormous volume of bloody work" (Trade Unionist and Clinical Specialist). Another path to scale is the diversification of services - with some companies coming from outside the health sector - 
such that low-paying treatments are cross-subsidised by more lucrative ones (Development Director Radiology 2).

Incumbent status was needed, according to our interviewees, to attain these high volumes. The NHS's fragmentation made it difficult for new market entrants to build relationships: "We've seen a lot of people mostly from across the Atlantic who've tried to break in [the English market] and I think why we're successful is because the vast majority of us, in particular senior positions, have been in the NHS, so understand it, can talk the language (Director Global Service Provider 2). Furthermore, incumbents could point to past success, which mitigated difficulties in demonstrating quality. Conversely, interviewees reported first-mover disadvantages due to high investment costs and lacking experience, track record, and relationships with the funder (NHS England Commissioner).

\section{Discussion and Conclusion}

This paper examines government efforts to increase privatisation in English healthcare through marketisation. By relating the market structure to general conditions of profitability we identify the barriers to profit-making and management strategies to mitigate them (see Table 1). Our assessment of the for-profit sector should be considered preliminary, and understanding the effects of marketisation on Trusts and non-profit providers is a matter for future research. However, much of what we find may persist due to the well-known path dependency of health systems (Wilsford, 1994), and our findings may resonate in other countries with NHS-style health systems (Böhm et al., 2013).

Table 1. The conditions of profitability in the English healthcare market 


\begin{tabular}{|c|c|c|}
\hline Barrier: Uncertainty in rules & $\begin{array}{l}\text { Market rules } \\
\text { Policy changes and reorganisation } \\
\text { Procurement practice } \\
\text { Contract length }\end{array}$ & $\begin{array}{l}\text { Lack of clarity over section } 75 \\
\text { Restructuring every } 2 \text { years } \\
\text { Lengthy, costly, and risky tendering exercises } \\
1 \text { year, often too short for return on investments }\end{array}$ \\
\hline $\begin{array}{l}\text { Barrier: Top-down price } \\
\quad \text { squeeze }\end{array}$ & $\begin{array}{l}\text { Impact of austerity measures } \\
\text { Private health insurance } \\
\text { Self-payers }\end{array}$ & $\begin{array}{l}\text { Squeeze on prices, limited public investment } \\
\text { Limited funding for elective procedures } \\
\text { Growing but marginal source of funding }\end{array}$ \\
\hline $\begin{array}{l}\text { Barrier: State dominance in } \\
\quad \text { funding and provision }\end{array}$ & $\begin{array}{l}\text { State dominance in funding } \\
\text { Quality and efficiency of public- } \\
\quad \text { sector provision } \\
\text { Public-sector economies of scale } \\
\text { Public-sector employment relations }\end{array}$ & $\begin{array}{l}\text { Providers depend on NHS commissioning } \\
\text { Funder reluctant to switch to private provision } \\
\text { Increasingly autonomous and competitive Trusts } \\
\text { Pay restraint, public-sector ethos }\end{array}$ \\
\hline Barrier: Failed depoliticisation & $\begin{array}{l}\text { Central government role } \\
\text { Anti-privatisation campaigns } \\
\text { Trade unions } \\
\text { Media attention }\end{array}$ & $\begin{array}{l}\text { Strong central government intervention } \\
\text { Strong local and national campaigning } \\
\text { High union membership and campaigning } \\
\text { High degree of critical media attention }\end{array}$ \\
\hline $\begin{array}{l}\text { Management practices: } \\
\text { reducing costs }\end{array}$ & $\begin{array}{l}\text { Unionisation } \\
\text { Skill levels } \\
\text { Performance Management } \\
\text { Asset Utilisation }\end{array}$ & $\begin{array}{l}\text { Lower union density and collective bargaining } \\
\text { coverage than NHS } \\
\text { Downbanding, i.e. deskilling } \\
\text { Tighter monitoring facilitated by IT systems and } \\
\text { standardisation } \\
\text { Higher patient turnover and longer running } \\
\quad \text { times of machines }\end{array}$ \\
\hline $\begin{array}{c}\text { Management practices: } \\
\text { increasing volumes }\end{array}$ & $\begin{array}{l}\text { Access to capital } \\
\text { Economies of scale } \\
\text { Incumbent status }\end{array}$ & $\begin{array}{l}\text { Private financing facilitated by investment } \\
\text { shortages in the NHS } \\
\text { Specialisation across large geography or } \\
\text { diversification of services } \\
\text { Advantages of big players through existing } \\
\text { relationships with NHS }\end{array}$ \\
\hline
\end{tabular}

For our private-sector interviewees, profits were difficult to realise partly because of austerity and the extraction of price concessions through efficiencies built into the tariff and through competitive tendering exercises that pit the private sector against low-cost and highquality NHS providers. On the other hand, especially in technology-driven segments like radiology and pathology, austerity could also lead to investment backlogs in the NHS. The private sector's access to capital was seen as creating opportunities to take over these services. Austerity thus had an ambivalent effect on profit-making.

Barriers to profitability identified by interviewees included the uncertainty built into the rules of this market, the dominance of the NHS as both funder and competitor, and by the high degree of public attention and staff resistance directed at privatisation attempts. Forprofits reported difficulty competing on the basis of price and quality with the NHS, and the 
complex relationship between politics and commissioning necessitated strategies by forprofits to avoid resistance from campaigners. Active profit-making strategies, according to our interviewees, consisted of cost-cutting and economies of scale, rather than qualitative innovation in care. This latter finding is striking, since innovation is one of the supposed reasons for marketisation and privatisation policies.

This study contributes to the international health policy literature by identifying profit-making as a precondition for privatisation in marketising healthcare systems and by generating a framework for understanding the conditions of profitability. While past studies have tended to assume that marketisation leads to privatisation, our framework helps to explain the limited extent of healthcare privatisation under marketisation in England. It opens the door to a more nuanced understanding of marketisation by identifying various dimensions of it that may promote or frustrate privatisation.

Our analysis implies that under the current framework private expansion in England will be concentrated at a few big players in the market segments with a previous history of privatisation and not as an encompassing takeover of healthcare. Achieving economies of scale is all the more necessary for these firms, since guaranteed payment above market rates, as in the early ISTC programme, is not practised anymore. Since this requires incumbent status, profit-making strategies may be reinforcing entry barriers, thus thwarting the Government's efforts to promote competition.

A final implication of our analysis is that the agency of workers and citizens matters in marketisation and is a major asset for the NHS. Campaigners have mounted a vigorous defence of the NHS, its workers, and its principles, and have kept health policy highly politicised. Private-sector managers argued that these political dynamics make investors wary, thereby inhibiting privatisation. Although campaigners may lack a strong voice in NHS reform, they have made the NHS a remarkably resilient public institution. 


\section{References}

Allen, P., \& Jones, L. (2011). Chapter 2. Diversity of health care providers. In A. Dixon, N. Mays, \& L. Jones (Eds.), Understanding New Labour's market reforms of the English NHS (pp. 16-29). London: King's Fund.

Anonymous (2013a) Details omitted for double-blind reviewing.

Anonymous (2013b) Details omitted for double-blind reviewing.

Arora, S., Charlesworth, A., Kelly, E., \& Stoye, G. (2013). Public payment and private provision. The changing landscape of health care in the 2000s. Nuffield Trust. Retrieved from http://tinyurl.com/prwh9zx

Bishop, S., \& Waring, J. (2011). Inconsistency in health care professional work: Employment in independent sector treatment centres. Journal of Health Organization and Management, 25(3), 315-331.

Böhm, K., Schmid, A., Götze, R., Landwehr, C., \& Rothgang, H. (2013). Five types of OECD healthcare systems: Empirical results of a deductive classification. Health Policy, 113(3), 258-269.

Brownlie, N. (2012). Trade Union Membership 2011. Department for Business, Innovation \& Skills. Retrieved from http://tinyurl.com/p9xalnq

Butler, P. (2013, November 11). NHS walk-in centre closures "will put more pressure on A\&E." The Guardian. Retrieved from http://tinyurl.com/m4rrhap

Callon, M., \& Muniesa, F. (2005). Peripheral Vision Economic Markets as Calculative Collective Devices. Organization Studies, 26(8), 1229-1250.

Campbell, J., Quincy, C., Osserman, J., \& Pedersen, O. (2013). Coding In-depth Semistructured Interviews: Problems of Unitization and Intercoder Reliability and Agreement. Sociological Methods \& Research, 42(3), 294-320. 
Carruthers, B. G., \& Ariovich, L. (2004). The Sociology of Property Rights. Annual Review of Sociology, 30(1), 23-46.

Coles, L. (2008). Report of the second phase of the review of NHS pathology services in England. Department of Health. Retrieved from http://tinyurl.com/pvgdmpo

Checkland, K., Allen, P., Coleman, A., Segar, J., McDermott, I., Harrison, S., Petsoulas, C., Peckham, S. (2013). Accountable to whom, for what? An exploration of the early development of Clinical Commissioning Groups in the English NHS. BMJ Open, $3(12)$.

CMA. (2014). Private healthcare market investigation. Final report. Retrieved from http://tinyurl.com/pqpml7c

Culpepper, P. (2010). Quiet Politics and Business Power. Cambridge: Cambridge University Press.

Davies, A. (2013). This Time, it's for Real: The Health and Social Care Act 2012. The Modern Law Review, 76, 564-588.

DOH. (2012). Payment by Results in the NHS: a simple guide. Retrieved from http://tinyurl.com/nf3agvq

DOH. (2009). Necessity - not nicety. A new commercial operating model for the NHS and the Department of Health. Retrieved from http://tinyurl.com/or9ggjd

Dicken, P. (2011). Global Shift, Sixth Edition: Mapping the Changing Contours of the World Economy. New York: Guilford Press.

Dowding, K., \& John, P. (2011). Voice and Choice in Health Care in England: Understanding Citizen Responses to Dissatisfaction. Public Administration, 89(4), 1403-1418.

Evans, R. (1997). Going for the gold: the redistributive agenda behind market-based health care reform. Journal of Health Politics, Policy and Law, 22(2), 427-465. 
Fligstein, N. (1996). Markets as Politics: A Political-Cultural Approach to Market Institutions. American Sociological Review, 61(4), 656-673.

Gabbay, J., le May, A., Pope, C., Robert, G., Bate, P., \& Elston, M.-A. (2011).

Organisational innovation in health services. Lessons from the NHS Treatment Centres. Bristol: The Policy Press.

Gingrich, J. (2011). Making markets in the Welfare State: The Politics of Varying Market Reforms. Cambridge: Cambridge University Press.

Gough, I. (1979). The Political Economy of the Welfare State. London: Macmillan.

Greer, S. (2008). Devolution and divergence in UK health policies. BMJ, 337.

Hebson, G., Grimshaw, D., \& Marchington, M. (2003). PPPs and the Changing Public Sector Ethos: Case-Study Evidence from the Health and Local Authority Sectors. Work, Employment \& Society, 17(3), 481-501.

Hellander, I., Himmelstein, D., \& Woolhandler, S. (2013). Medicare overpayments to private plans, 1985-2012: shifting seniors to private plans has already cost Medicare US\$282.6 billion. International Journal of Health Services: Planning, Administration, Evaluation, 43(2), 305-319.

HM Treasury. (2013). Spending Review 2013. Retrieved from http://tinyurl.com/nvyo6ud Horwitz, J. (2005). Making Profits And Providing Care: Comparing Nonprofit, For-Profit, And Government Hospitals. Health Affairs, 24(3), 790-801.

Hunter, D. (2013). Will 1 April mark the beginning of the end of England's NHS? Yes. BMJ, 346.

Hyde, P., Harris, C., Boaden, R., \& Cortvriend, P. (2009). Human relations management, expectations and healthcare: A qualitative study. Human Relations, 62(5), 701-725. 
Jensen, C. (2011). Marketization via Compensation: Health Care and the Politics of the Right in Advanced Industrialized Nations. British Journal of Political Science, 41(04), $907-$ 926.

Keegan, C., Thomas, S., Normand, C., \& Portela, C. (2013). Measuring recession severity and its impact on healthcare expenditure. International Journal of Health Care Finance and Economics, 13(2), 139-155.

Klein, R. (2006). The New Politics of the NHS. From creation to reinvention. Abingdon: Radcliffe.

Klein, R. (2005). The public-private mix in the UK. In A. Maynard (Ed.), The Public-private Mix for Health: Plus Ça Change, Plus C'est la Même Chose? (pp. 43-62). Abingdon: Radcliffe.

Le Grand, J. (2013). Will 1 April mark the beginning of the end of England's NHS? No. $B M J, 346$.

Lethbridge, J. (2011). Understanding multinational companies in public health systems, using a competitive advantage framework. Globalization and Health, 7(1).

Leys, C., \& Player, S. (2011). The Plot Against the NHS. Pontypool: Merlin Press.

Light, D. (2001). Managed competition, governmentality and institutional response in the United Kingdom. Social Science \& Medicine, 52, 1167-1181.

Light, D., \& Connor, M. (2011). Reflections on commissioning and the English coalition government NHS reforms. Social Science \& Medicine, 72, 821-822.

Lister, J. (2012). In defiance of the evidence: conservatives threaten to "reform" away England's National Health Service. International Journal of Health Services: Planning, Administration, Evaluation, 42(1), 137-155. 
Lonsdale, C., \& Watson, G. (2007). Managing contracts under the UK's Private Finance Initiative: evidence from the National Health Service. Policy \& Politics, 35(4), 683700.

Midttun, L., \& Hagen, T. (2006). The private-public mix of healthcare: evidence from a decentralised NHS country. Health Economics, Policy, and Law, 1(Pt 3), 277-298.

Moody, K. (2011). Capitalist care: Will the Coalition government's "reforms" move the NHS further toward a US-style healthcare market? Capital \& Class, 35(3), 415-434.

Nabarro \& HealthInvestor (2013) The Healthcare Industry Barometer 2013. Retrieved from: http://tinyurl.com/p52nloo

NHS England (2014) See: http://www.england.nhs.uk/allocations-2013-14/ (accessed 21.06.14).

NHS North West London. (2013). Shaping a healthier future. Decision making business case. Volume 1. Retrieved from http://tinyurl.com/ohfpl8e

NHS Support Federation. (2013). CONTRACT ALERT. April - Dec 2013. Retrieved from http://tinyurl.com/oyq6fz2

Office of Manpower Economics. (2013). NHS Pay Review Body. Twenty-Seventh Report. Retrieved from http://tinyurl.com/ockodxv

OECD. (2013). Health at a Glance 2013. Paris: Organisation for Economic Co-operation and Development. Paris: OECD.

O’Reilly, J., Busse, R., Häkkinen, U., Or, Z., Street, A., \& Wiley, M. (2012). Paying for hospital care: the experience with implementing activity-based funding in five European countries. Health Economics, Policy and Law, 7(1), 73-101.

Patton, M. (1999). Enhancing the quality and credibility of qualitative analysis. Health Services Research, 34(5 Pt 2), 1189-1208. 
Peedell, C. (2011). Further privatisation is inevitable under the proposed NHS reforms. BMJ, 342.

Petsoulas, C., Allen, P., Hughes, D., Vincent-Jones, P., \& Roberts, J. (2011). The use of standard contracts in the English National Health Service: A case study analysis. Social Science \& Medicine, 73, 185-192.

Player, S., \& Pollock, A. (2001). Long-term care: from public responsibility to private good. Critical Social Policy, 21(2), 231-255.

Pollock, A., \& Price, D. (2011). The final frontier: The UK's new coalition government turns the English National Health Service over to the global health care market. Health Sociology Review, 20, 294-305.

Propper, C., \& Bartlett, W. (1997). The impact of competition on the behaviour of national health service trusts. In R. Flynn \& G. Williams (Eds.), Contracting for Health. Quasi-Markets and the National Health Service. (pp. 14-29). Oxford: Oxford University Press.

Propper, C., \& Dixon, J. (2011). Chapter 6. Competition between hospitals. In A. Dixon, N. Mays, \& L. Jones (Eds.), Understanding New Labour's market reforms of the English NHS (pp. 78-88). London: King's Fund.

Radnor, Z. J., Holweg, M., \& Waring, J. (2012). Lean in healthcare: the unfilled promise? Social Science \& Medicine, 74(3), 364-371.

Rees, J., Miller, R., \& Buckingham, H. (2014). Public sector commissioning of local mental health services from the third sector. Working Paper 122. Retrieved from http://tinyurl.com/plt3avj

Ruane, S. (2011). "Save our hospital” campaigns in England: why do some hospital campaigns succeed? ; a preliminary exploration. In J. Lister (Ed.), Europe's Health for Sale. The Heavy Cost of Privatisation. (pp. 125-148). Faringdon: Libri. 
Scambler, G. (2009). Capitalists, workers and health: Illness as a "side-effect" of profitmaking. Social Theory \& Health, 7(2), 117-128.

Schoen, C., Osborn, R., Squires, D., \& Doty, M. (2013). Access, Affordability, And Insurance Complexity Are Often Worse In The United States Compared To Ten Other Countries. Health Affairs, 32(12), 2205-2215.

Sheaff, R., Chambers, N., Charles, N., Exworthy, M., Mahon, A., Byng, R., \& Mannion, R. (2013). How managed a market? Modes of commissioning in England and Germany. BMC Health Services Research, 13(Suppl 1), S8.

Turner, S., Allen, P., Bartlett, W., \& Pérotin, V. (2011). Innovation and the English National Health Service: a qualitative study of the independent sector treatment centre programme. Social Science \& Medicine (1982), 73(4), 522-529.

West, P. (1997). Understanding the National Health Service reforms. The creation of incentives? Buckingham: Open University Press.

Wilsford, D. (1994). Path Dependency, or Why History Makes It Difficult but Not Impossible to Reform Health Care Systems in a Big Way. Journal of Public Policy, 14(03), 251-283.

WHO (2014). Global Health Observatory Repository. Retrieved from http://tinyurl.com/nzf6136 and http://tinyurl.com/pkd96a9 